\title{
Agricultural sustainability in the semi-arid Near East
}

\author{
F. Hole \\ Department of Anthropology, Yale University, New Haven, CT, USA \\ Received: 8 May 2006 - Published in Clim. Past Discuss.: 21 July 2006 \\ Revised: 29 March 2007 - Accepted: 19 April 2007 - Published: 11 May 2007
}

\begin{abstract}
Agriculture began in the eastern Mediterranean Levantine Corridor about 11000 years ago toward the end of the Younger Dryas when aridity had diminished wild food resources. During the subsequent Climatic Optimum, agricultural villages spread rapidly but subsequent climatic changes on centennial to millennial scales resulted in striking oscillations in settlement, especially in marginal areas. Natural climate change thus alternately enhanced and diminished the agricultural potential of the land. Growing populations and more intensive land us, both for agriculture and livestock, have led to changes in the structure of vegetation, hydrology, and land quality. Over the millennia, political and economic interventions, warfare and incursions by nomadic herding tribes all impacted sustainability of agriculture and the ability of the land to supports its populations. In much of the region today, agricultural land use is not sustainable given existing technology and national priorities. The Near Eastern case is instructive because of the quality of information, the length of the record, and the pace of modern change.
\end{abstract}

\section{Introduction}

Agricultural sustainability must be seen against a background of natural decadal to centennial climatic variability, as well as annual to decadal social, economic and technological changes that impact the land. In this paper I outline the history of agriculture, the environmental characteristics of the semi-arid Near East, and then discuss long and shortterm climatic and social changes in one well-known region to establish antecedent conditions for helping to understand the present and possibly forecast the future. Using documentary and observational evidence for the last century, I identify drivers of change and assess the potential sustainability of the present system, which, in many ways is paralleled in similar environments worldwide.

Correspondence to: F. Hole

(frank.hole@yale.edu)

\section{Agricultural history}

Humans began to tame and exploit wild species only about 11000 years ago after several million years of collecting plant food and hunting game (Bar-Yosef and BelferCohen, 2002; McCorriston and Hole, 1991). During the pre-agricultural period humans had little impact on the earth other than cutting trees and shrubs for fuel and occasionally setting dry vegetation on fire. This benign impact on the earth began to change dramatically with the adoption of farming and stock raising. Native vegetation was degraded or replaced by cultivars, and soils were depleted of nutrients and exposed to erosion. Invasive domesticated plants and their weedy followers altered species compositions and biodiversity. Agriculture raised the carrying capacity of the land many fold and, through storage and trade, people were able to buffer natural variability of food resources. With sedentary life and potential for surplus production, human populations increased and rapidly colonized the best arable land. In the beginning, agriculture existed in a virgin land of plenty, but through the millennia this natural bounty was interrupted time and again by short and long-term changes in weather patterns, disease, depletion of resources and hostile competition among human groups. These factors resulted in uneven exploitation of the land, with short periods of intensification followed by longer periods of abandonment or lower levels of production that allowed the land to regenerate. When new techniques and technology were introduced (such as irrigation, and the plow) the carrying capacity of the land increased still further, with the inevitable result that populations and their impacts on the land also grew.

\section{The age of agriculture}

Agriculture is a phenomenon of the Holocene, beginning in the Near East some 11000 years ago in the Levantine Corridor, a narrow strip of land that straddles a geological fault that runs from the Gulf of Aqaba to southeastern Turkey (Fig. 1). Climate, rapid increases in $\mathrm{CO}_{2}$ and unique

Published by Copernicus Publications on behalf of the European Geosciences Union. 


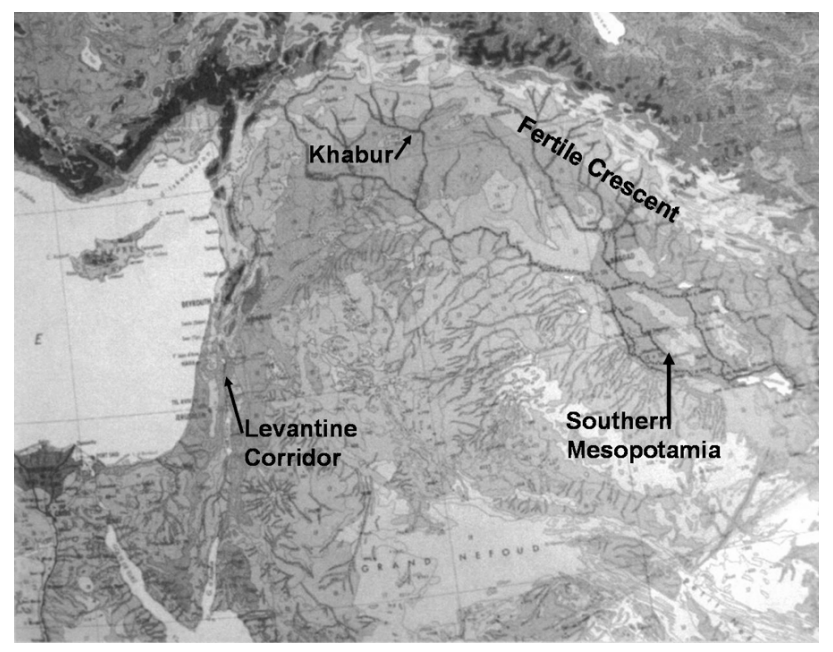

Fig. 1. The Levantine Corridor and Fertile Crescent.

geography controlled the timing and location of the first agriculture (Blumler, 1996; McCorriston and Hole, 1991; Moore and Hillman, 1992; Sage, 1995; Zohary, 1989). The Near East lies within the Mediterranean climate zone in which all effective precipitation falls during the cool winter months, and summers are hot and dry. Because of this intense seasonality, annual vegetation ripens in the spring and lies dormant through the summer. While this is the prevailing climatic pattern throughout the Holocene there have been significant deviations on centennial and millennial scales.

Native species, with their large seeds, comprise the eight "founder crops" that characterize Near Eastern and, indeed, much of the world's diets today (Table 1). These crops are: emmer and einkorn wheat, barley, lentils, peas, vetch, chickpea and flax. Agriculture also includes livestock: goats and sheep, pigs and cattle. When animals were incorporated into the cereal-based economy, we may truly say that the "agricultural revolution" had begun. By 8000 years ago, an economy of agriculture and livestock had fueled a spread of settlements from the Mediterranean across Turkey to Iran and into Southeastern Europe and onto the Island of Cyprus. We can imagine a hundred-fold increase in human populations with their needs for fuel, food and construction materials. Each settlement had a corona of intensely trampled, cultivated, and stripped land, in the midst of vast fields of virgin landscape.

When ox-drawn plows were introduced, probably in the fourth millennium BC, the areas under cultivation expanded and became more susceptible to wind and water erosion. The use of irrigation, established as early as the sixth millennium $\mathrm{BC}$, likewise expanded cultivated areas, greatly increased yields, but also raised water tables and left deposits of salt. Even simple technology allowed greater production, but set in motion processes of landscape degradation that continue today and whose legacy is vast stretches of barren ground
Table 1. Founder crops and animal domesticates.

\begin{tabular}{ll}
\hline Emmer wheat & Triticum dicoccoides \\
Einkorn wheat & Triticum monococcum \\
Barley & Hordeum distichum \\
Lentil & Lens culinaris \\
Pea & Pisum sativum \\
Chickpea & Cicer arietinum \\
Flax & Linum usitatissimum \\
Bitter vetch & Vicia sativa \\
\hline Goat & Capra aegagrus \\
Sheep & Ovis orientalis \\
Pig & Sus scrofa \\
Cattle & Bos primigenius \\
\hline
\end{tabular}

and blowing sand. Archaeology and history show that over the millennia people implemented increasingly labor- and capital-intensive means to ensure sustained agricultural production. In effect, there has been an "arms race", in which people used technology and manpower to overcome problems, which led to further problems - such as salinization and depletion of groundwater - that had to be fixed through further adjustments. Until human ingenuity fails or the land is irreversibly degraded, this race will continue.

I have referred to technical fixes to problems, but there have also been social fixes in the form of changes in the organization of society. The first farmers worked in family units, loosely grouped into communities. As these communities grew, so did leadership. In time, leaders became powerful enough to adopt the title of King and even Emperor. The most notable of these became predatory, conquering neighboring states and dominating whole regions. Such leaders could also command armies and build cities, dig canals and engage in long-distance trade that changed the political, economic and hydrological landscape. Today, nation states assume this role with similarly profound impact within constrained borders.

\section{The broader Near Eastern region}

The Near East comprises an arc of mountains embracing relatively flat steppe and desert that extends southward to Arabia (Fig. 2). At the base of the mountain arc lies the Fertile Crescent, a narrow stretch of land where rain-fed agriculture is possible. Southward of this, the land grows progressively drier and is best used as seasonal pasture for herds of sheep and camels. The monotony of the arid landscape is broken by the Tigris and Euphrates Rivers. These rivers provide axes of transport, lush vegetation, and aquatic food resources: a rich and productive, irrigation-based agriculture in lower Mesopotamia has been in operation for more than 7000 years. These factors enabled the development of a network of small cities that periodically coalesced into states 


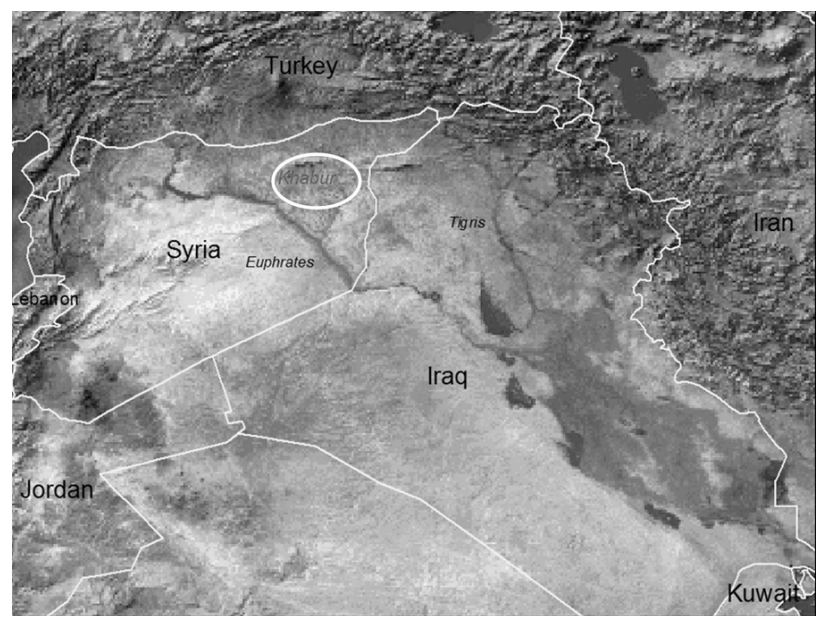

Fig. 2. The semi-arid region of the Khabur in the context of the Tigris-Euphrates basin.

and empires. Over the millennia the natural hydrology of the region was transformed through the construction of weirs and canals. These efforts took place while the rivers themselves shifted their beds and created new channels, and rising sea-level led to a rapidly encroaching Gulf (Gasche and Tanret, 1999; Hole, 1994). In other words the natural environment has been ever-changing and unstable, in part a result of human activities, such as construction of canals that diverted water, but also in response to changes in climate and sea-level. The land also suffered from salinization brought about by the combination of irrigation, high water table and extreme evaporation. Despite such contingencies, civilization in Southern Mesopotamia - the heartland of cities and civilization - has faltered but never completely collapsed (Adams, 1981).

It is instructive to contrast this situation with that of the rain-fed Fertile Crescent and particularly with its lowerrainfall margins where human settlements have expanded and contracted in response to climate changes and sociopolitical-economic events rather than changes in hydrology. The broad stretch of Fertile Crescent that lies between the Euphrates and Tigris rivers is known as the Jazirah. During the Holocene, the Jazirah has generally been arid, but punctuated by brief periods of favorable precipitation as well as by periods of hyper aridity. In a region where successful agriculture depends on the amount and timing of rain, changes of 10-20\% over several successive years can encourage expansion of agriculture or destroy it (Fig. 3). When favorable years stretch into decades, agriculture expands, but populations become more vulnerable to a reversal of trends. We can monitor these fluctuations through archaeology in the regions most sensitive to change - at approximately the $200-250 \mathrm{~mm}$ precipitation isohyet which defines the limits of rain-fed agriculture today. The evidence is the waxing and waning of settlement in this zone, as well as in the size and density of
Table 2. Traditional buffers to sustainability.

- Unexploited (virgin) land

- Land races, genetic diversity and wild resources

- Fallow cycles

- Multi-crop subsistence farming

- Ability to shift between agriculture and livestock herding

- Storage and trade

villages and towns. This evidence shows that major fluctuations on the order of 1000-1500 years recur independently of political conditions in the Near East as well as other northern temperate regions (Hole, 1997a; Mensing et al., 2004). The frequency and timing of these correspond, within the limits of dating, to natural millennial cycles (Bond et al., 1997; Bond and Lotti, 1995).

As paleoclimate studies, both globally and in the Near East, have become more specific and tightly controlled chronologically it is evident that sharp decadal changes in climate had widespread effects on human activities (Hassan, 2002; Hole, 1997a; Issar and Zohar, 2004; Nester, 1998). The evidence for this lies primarily in coincidental affects because rarely do archaeological data inform directly on climate; rather it is the pattern of cultural activities, aligned chronologically with known climate events that allows us to make the case.

The ability of people to adapt to natural fluctuations in precipitation determines sustainability in the semi-arid zone. Traditional cultures maintained a flexibility of shifting between agriculture and herding according to circumstances and they often maintained settlements that were used only seasonally (Table 2). The Fertile Crescent lies within a climate regime that has a high degree of variability from year to year. Because unproductive agricultural years could be anticipated, people developed means to cope that included storing surpluses, moving with herds, trade, raiding and warfare. Nevertheless, if climate changes approached the reported severity and abruptness of those in many parts of the world, buffering options would have been reduced. This would have been "particularly harmful where the individual entities have long lifetimes or are relatively immobile", as would have been the case with established agricultural communities (Alley et al., 2003). Today the situation is much more complex because use of farm machinery, ground water and fertilizer, along with subsidized production and trade, have allowed producers to mitigate both natural climatic variability and inherent environmental limits such as low precipitation. Like additional precipitation in the past, these new sources of control have encouraged expansion and intensification of 

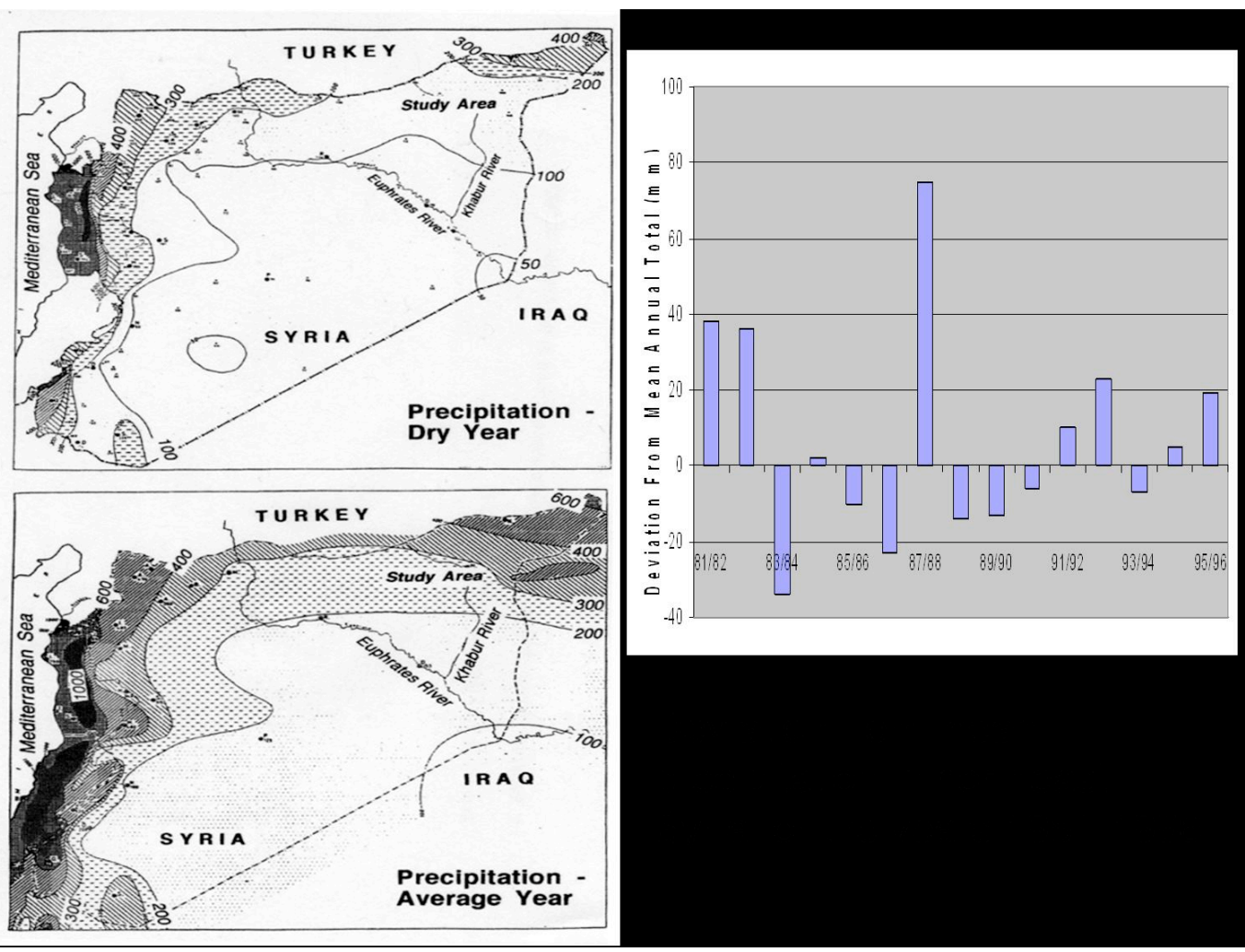

Fig. 3. Difference between average precipitation and drought in Syria. Deviation from mean precipitation in Northeastern Syria in the Khabur drainage for the years 1981-1996 (contours in millimeters).

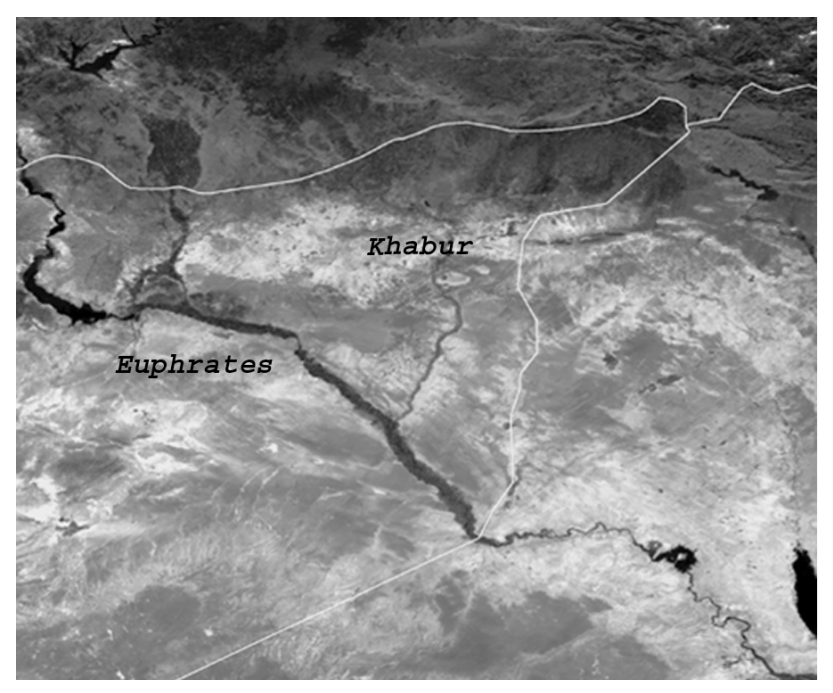

Fig. 4. Location of the semi-arid steppe discussed in this text.

agriculture well beyond the ability of the systems to regenerate through natural processes.

Eleven thousand years after the first crops were sown, the health of land on which agriculture depends is imperiled even without the traditional factors of climate change, incursions by marauding tribes, state warfare and draconian taxation. Neither peace nor stable climate can ensure a sustainable future. The remainder of this paper discusses our knowledge of one region of the Near East to illustrate themes that are common throughout the region.

\section{The Khabur Basin}

To illustrate the past, the present, and the potential sustainability of agriculture I have chosen as a case study, the Khabur Basin of northeastern Syria where I have had many years of experience studying the ancient past as well as modern land use (Fig. 4). In particular I focus on the sensitive marginal zones (200-250 mm precipitation) where rain-fed agriculture merges with grazing land and change, owing to external circumstances, is most evident. The Khabur is an analog for other similar regions of the northern part of the Near East, and in its recent development it also exemplifies social processes common to the entire Fertile Crescent. The modern pace and direction of change in the Khabur is paralleled throughout the Near East and indeed throughout much of the world. 
The Khabur region is part of the north Mesopotamian Jazirah, the semi-arid steppe between the Tigris and Euphrates rivers. The northern Jazirah has fertile soils and sufficient precipitation to support rain-fed agriculture, but within 50 $\mathrm{km}$ south of the Turkish border, subsistence agriculture is problematic and the situation grows progressively worse the farther south one goes. Interannual variability in precipitation can exceed $100 \%$ and drought years are not uncommon so that crops benefit from irrigation even in the wetter regions and it is indispensable in the drier (Fig. 3). Traditional agriculture depended on fall-sown cereals that ripen in late spring, but with the advent of irrigation two cropping seasons has become the norm, with grain in the winter and cotton or another water intensive cash crop in summer.

\subsection{Archaeological history}

Let us now turn to the past. Briefly, severe and rapid changes of climate as well as pervasive political conflict, have had major a impact on societies. As a consequence, the archaeological history of the drier regions of the Khabur is one of relatively brief episodes of settlement, each lasting several hundred years, separated by a thousand or more years when settlement was sparse and the land was used chiefly by mobile herders and hunters (Hole, 1997b, 2000, 2002) (Table 3).

When the Near East emerged from the Younger Dryas about 9000 BC the Khabur region had no permanent settlements, and the land was frequented only by small bands of hunters. As the climate improved during the Holocene Climatic Optimum, about $7000 \mathrm{BC}$, people began to settle close to the flood plain of the Khabur River. For the next three thousand years the plain itself was sparsely settled along tributary streams, and sites generally remained small, short-lived and dependent on rain-fed agriculture.

Across the Near East there was a general retraction of settlement from dry areas as the Climatic Optimum was waning and aridity set in, seemingly part of a global event (Alley et al., 2003; Bond et al., 1997). Proxy data indicate a widespread multi-century climatic deterioration that peaked around 6200 BC (Alley, 1997; Bond et al., 1997; Dean et al., 2002; Grafenstein et al., 1999; Rohling and Pälike, 2005). After a prolonged period in which settlement slowly rebounded, once again, beginning around $4500 \mathrm{BC}$, there was another abandonment of settlement across the Near East, a change that affected even the proto-urban temple centers in Southern Mesopotamia. A shift of the Intertropical Convergence Zone (ITCZ), which changed precipitation patterns may have reduced agricultural possibilities (COHMAP, 1988; Hole, 1994; Kouchoukos, 1998). Speleothems from Soreq Cave in Israel indicate a wetter period prior to 4500 $\mathrm{BC}$, and a sharp change thereafter to a climate more similar to today's (Bar-Matthews et al., 1998; Bar-Matthews et al., 1999).

The dry region of the Khabur saw virtually no human activity for several hundred years although in the wetter zones,
Table 3. Climate and settlement in the semi-arid zone.

HOLOCENE CLIMATIC OPTIMUM 9000-4000 BC

- First agricultural settlements, ca 7000 BC

- Small sites until ca 4000 BC

ARID EVENT, ca 4200 BC

- Hiatus in settlement 4000-3000 BC

INCREASED PRECIPITATION ca 2600-2200 BC

- Early Bronze Age large towns, small sites, maximum population

VERY ARID EVENT 2200-2900 BC

- Collapse of Akkadian and Old Kingdom

- Nomadic tribes in Khabur by 2000 BC

- Neo-Assyrian Iron Age, ca. 1000-700 BC, small sites, herders; town on lower Khabur

HIATUS 700-200 BC

- Nomadic sheep herding tribes

ROMAN WET PERIOD 90 BC-240 AD

- Forts and small farmsteads

ARID PERIOD

- Arab conquest from 640 AD

- Small sites and some irrigation

ARID PERIOD IN 1200s?

- Mongol invasion 1260 AD

- Abandonment of settlements

- Nomadic tribes

LITTLE ICE AGE 1400-1850 AD

- Ottoman government 1600-1915

- Few settlements, nomadic tribes

FRENCH MANDATE 1925-1946

- Settlement of nomads and refugees

SYRIAN STATE 1946-PRESENT

- Intensive agricultural development

settlements, some combining tent camps with villages, had emerged and by $3500 \mathrm{BC}$ some of these had grown to the size of small towns with elaborate architecture and temples. Once again there was a crisis of intense aridity that affected populations throughout the Near East, contributing to the collapse of the earliest Mesopotamian city states around 3200 BC. After several hundred years, small, early 3rd millennium BC settlements were placed along the river but the greater amount of land was used for grazing. However, by 2600 BC settlement had moved onto the semi-arid steppe or along a tributary stream of the Khabur. The previous pattern 


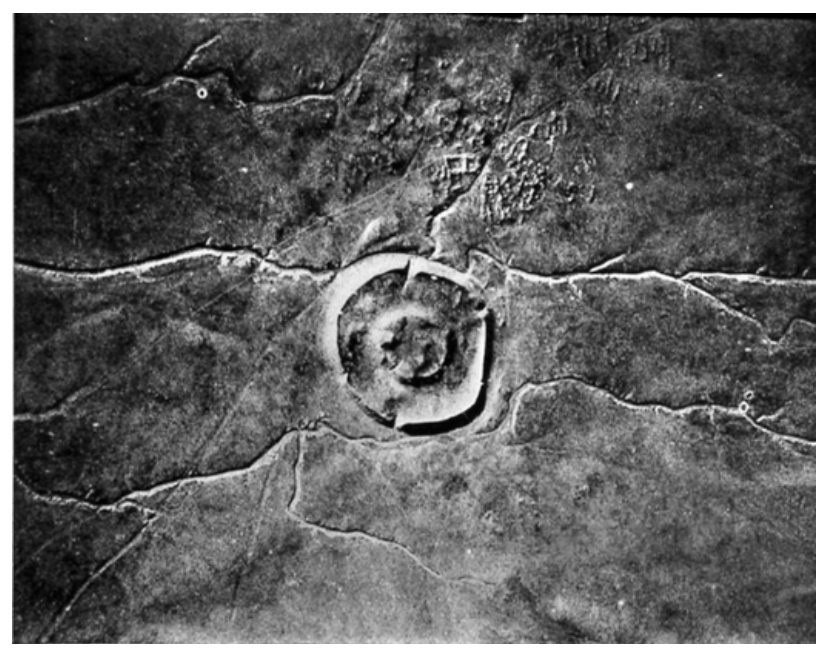

Fig. 5. Early Bronze Age (Third Millennium BC) town enclosed by circular wall on the arid Khabur steppe. Wall is about $500 \mathrm{~m}$ in diameter.

of sparse settlement and low intensity of land use changed markedly when a number of towns and many small hamlets filled up the landscape (Kouchoukos, 1998). Some of the larger towns were walled and enclosed palaces, temples and large granaries that were situated on high mounds (Fig. 5). These appear to be roughly comparable in type if not in scale with the city states of the south and their development may, in part, have been a result of demand for wool by southern elites (Akkermans and Schwartz, 2003). From the vastly increased number of settlements and the move to the dry steppe, unsuited to rain-fed agriculture or gravity irrigation today, we inferred that effective precipitation must have been greater (Hole, 1997a). This inference has subsequently been corroborated by proxy climate evidence that suggests a 20 $25 \%$ increase in precipitation, including heavy flooding in Mesopotamia (Avner, 1998; Bar-Matthews et al., 1998; Issar and Zohar, 2004:18, 101). While greater rainfall may have enabled the spread of settlements, increased demand for wool encouraged exploitation of the steppe for grazing (Buccellati, 1990; Hole, 1997a, b; Margueron, 1991).

In the best agricultural zone in the northern part of the Khabur plain, several large cities formed. The prosperity lasted for only about 300 years and it was ended by a prolonged period of intense aridity that has been registered around the world starting around $2200 \mathrm{BC}$. This resulted in the abandonment of nearly all sites, even those in the wetter areas (Weiss, 1997), and includes the demise of the Egyptian Old Kingdom (Hassan, 1984). Not until the modern era, has settlement in the Jazirah again been as widespread and intensive as in the Early Bronze Age. While a period of severe aridity seems well established and may, by itself, have resulted in the collapse of the polities, some have argued (Wilkinson, 1994, 1997) that the density of population

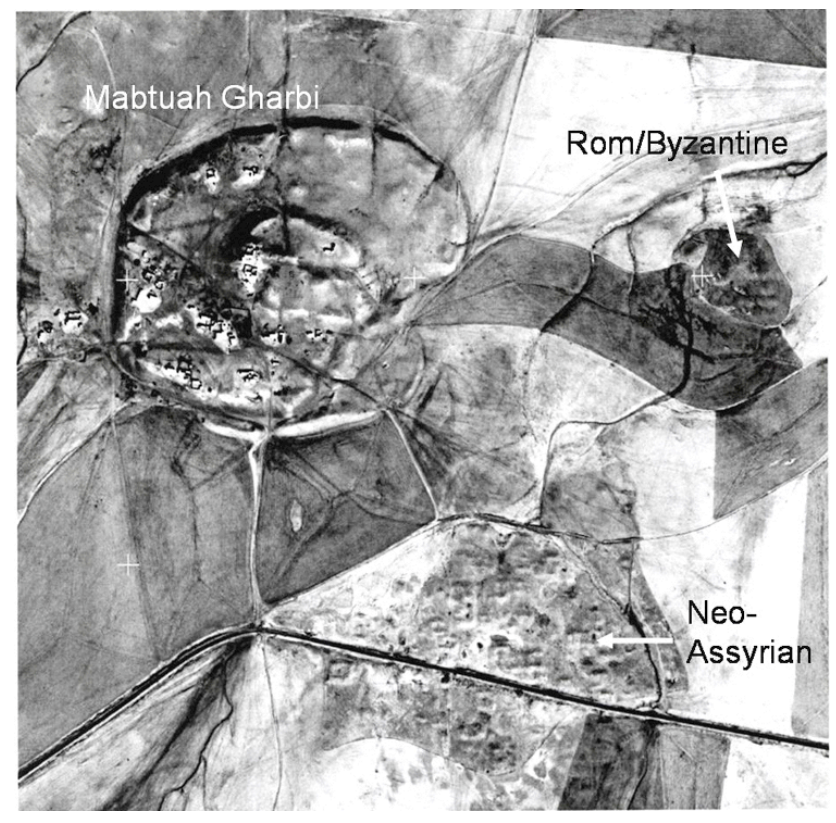

Fig. 6. Tell Mabtuah Gharbi, an Early Bronze Age walled town, with a Neo-Assyrian settlement and a small Roman/Byzantine farmstead. The maximum diameter of the wall is $600 \mathrm{~m}$.

and its need for agricultural products may have contributed to over-exploitation and degradation of the land. In other words, over-specialization on agriculture and herding may have played a role in the collapse. For whatever causes, agricultural systems of the day were stressed beyond resilience. Throughout the region, sites were abandoned or much reduced in size and there was a distinctly rural appearance to settlements that did continue. After a few centuries when conditions improved, there was another fundamental shift in social organization.

The Middle Bronze Age (2000-1600 BC) of northern Syria saw the emergence of numerous small kingdoms that were often at war with one another (Akkermans and Schwartz, 2003), but in the semi-arid Khabur, there is a notable absence of consequential settlements. Cuneiform texts from the site of Mari on the Euphrates, describe sheepherding nomadic tribes living in the Khabur, with Tell Leilan as a local political capital (Buccellati, 1990; Luke, 1965).The MBA was thus characterized by a mix of farming with extensive nomadic herding, an impact on the land that was significantly lower than it had been in the late third millennium.

The Late Bronze Age (1600-1200 BC) saw northern Syria become a battle ground where empires contested (Akkermans and Schwartz, 2003). For some two centuries, the Khabur was the heartland of the Mitannian state, whose principal remains are palaces atop several of the existing abandoned mound sites. Around 1200 BC the urban centers and political systems of the region again collapsed. While causes are not clear and environmental degradation 
has been invoked, it seems likely that a combination of climate changes (Neumann and Parpola, 1987), constant warfare and destruction of sites by burning (Akkermans and Schwartz, 2003:359), may have made life itself, let alone agriculture, unsustainable.

As a general picture, the city-based, palace-centered economies of the LBA were replaced by regional states in the Iron Age (Akkermans and Schwartz, 2003:360). At least by the 8th century BC, if not earlier in the LBA, there were canals running along the lower Khabur, with extensive irrigation systems at sites well outside the zone of rain-fed agriculture. The Neo-Assyrian capital of Dur Katlimu on the lower Khabur dominated the region (Kühne, 2000), but in the upper Jazireh, there was only a proliferation of small farmsteads, villages and herding camps (van Berg and Picalause, 2003; van Berg et al., 2004), which may have supplied agricultural products to the center (Fig. 6). The Neo-Assyrian empire was destroyed by the Neo-Babylonian empire which, in turn, fell to the Achaemenid empire. Throughout these tumultuous times, there is little evidence of activity in the semi-arid Khabur. In other words the landscape was largely in a regenerative state.

In 330 BC, the Near East fell to Alexander's armies, which ushered in a lengthy period of Greek and Roman culture and domination during which the climate was colder and more humid, allowing expansion into the desert fringe of the Levant (Issar and Zohar, 2004). In the Khabur, The Romans maintained a series of fortifications as a line of defense against the Persians, but only small agricultural settlements dotted the landscape (Kennedy and Riley, 1990). By 640 $\mathrm{AD}$ the entire Jezireh was conquered by the Arabs who established small farms on spring-fed wadis and used the river for small-scale irrigation (Robinson, 1996). The Arab conquest and expansion out of Arabia is often attributed to a period of aridity (Enzel et al., 2003; Enzel et al., 1999; Issar and Zohar, 2004:213; Keys, 1999). Settlement was again disrupted in the 13th century when the Mongols, who also may have responded to worsening conditions on the Central Asian steppe, laid waste to the region. At this time the Dead Sea registered its lowest level in a thousand years and dunes encroached on the southern Levant (Nester, 1998:133).In the 14th century the Arab geographer Ibn Batuta "found the district already waste and desolate" (Epstein, 1940). From the 16th to the 20th centuries, the Khabur was under Ottoman administration, and agriculture spread only when there was peace between the various nomadic tribes that occupied the area seasonally (Hütteroth, 1992; Pascual, 1980).

\subsection{The modern era}

In 1850, the famous English diplomat-archaeologist, Austen Henry Layard described the middle Khabur. "The richness of its pastures, the beauty of its flowers, its jungles overflowing with animals of all species, its huge trees providing delicious shade against the brilliant sun, all form a terrestrial paradise"

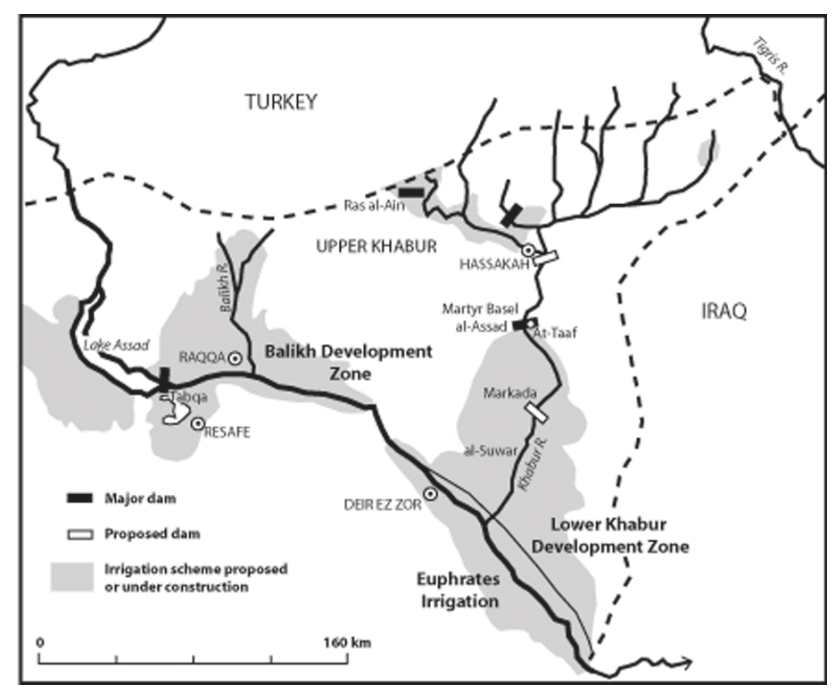

Fig. 7. Irrigation schemes for the Khabur and Balikh drainages developed in the 1960 s.

(Layard, 1853:235). While he may have been guilty of some exaggeration, the land was effectively virgin territory ready again to be exploited. As late as 1880 a traveler reported finding, "no villages, no cities, only tents and ruins" (Sachau, 1883:296). This situation was not to last, for the late 19th century saw the settlement of refugees from Russia. After the First World War, with defeat of the Ottomans and the ceding of Syria to the French, pacification of the tribes began (Charles, 1939) and refugees from Iraq and Turkey were settled along the Khabur River (Dodge, 1940). Development was slow during the first half of the 20th century owing to conflict among the various ethnic and religious groups and rebellions against the French.

Following the founding of the Syrian State in 1946, tribal administration of the steppe was abolished (Hole and Smith, 2004). The State encouraged the Bedouin to settle, but when they did, continuous occupation of the grazing lands and loss of the winter/summer grazing rotation, prevented the regeneration of forage plants. "Groundwater use has transformed sustainable traditional livestock-barley farming into unsustainable groundwater-irrigated system, leading to outmigration once the groundwater was depleted (Rida et al., 2004:64-65). The 1950s also saw the introduction of farm machinery, diesel pumps, and the opening of the steppe to speculative cultivation. These combined to allow an unprecedented intensity of exploitation which proved ruinous to the native shrubs and fodder for the herds. Now the government has to provide nearly all the food for the animals (Hole and Smith, 2004).

In the 1960s the Syrian government invited foreign experts to assess water resources, agricultural potential, and possibilities for developing extensive irrigation systems (FAO, 1966; USAID, 1982; USDA, 1979). Plans for the construction of 
Table 4. Lessons from past experience.

- Climatic and environmental changes are inevitable

- Marginal zones are especially vulnerable

- Catastrophe is usually followed by political changes

- Rain-fed agriculture with fallow can be sustained

- Costs of sustaining irrigation agriculture are increasing

Costs of remediation may be out of reach.

large water reservoirs and canal systems were laid and eventually implemented in the late 1990s (Fig. 7). By the time these systems were in place, however, the population of the region had burgeoned and thousands of individual wells had been drilled into the steppe in Syria, as well as in the headwaters of the Khabur River in Turkey. The Syrian government annually plans production levels and guarantees prices of cotton and wheat for farmers. Moreover, the farmers are provided seed, fertilizer, farm equipment, and they benefit from low fuel prices, and loans. The result has been an annual increase of some $6 \%$ in cotton production and a doubling of wheat from the late 1980s to 1990s (Rida et al., 2004).

Belatedly it has been discovered that early estimates of the regenerative capacity of the ground water were seriously over-estimated. The result of the state-planned projects, the attempt to maximize summer cash crops, and the drilling of thousands of wells, was to change the picture of agriculture and stock-raising from one dependent on natural cycles to one based wholly on artificial water supply. With water considered a common good to be freely exploited, it soon became depleted to the extent that the river no longer flows, and fields had to be abandoned when ground water became too brackish to use, or the water table dropped below the level of economical pumping (Glennon, 2002). Extensive summer cultivation of cotton on the steppe, drawing on ground water, was unsustainable and its cultivation has now been banned. Since farmers depended on this source of income, their agricultural way of life is at least temporarily unsustainable. Now migration of workers from failed farms to cities for wage labor is on the rise (Rida et al., 2004).

As archaeology and history show, agriculture in the Khabur fails periodically, usually as a result of lowered precipitation. Today sustainability may depend on employing a less intensive system of traditional fallowing and using only supplemental irrigation of winter crops. Where summer irrigation can be sustained by use of surface water drawn from the reservoirs, the construction of more efficient canals and
Table 5. Unique qualities of the modern era.

- Size of human population

- Demand on the natural systems

- Loss of biodiversity

- Invasive species

- Rate of degradation of land and water

- Depletion of non-renewable resources

- Human impact on climate

the use of drip irrigation or crops that are less water intensive, may enable more of the water to actually be used, and prolong summer cropping. However, the cost of providing new facilities in the absence of equivalent economic benefit may be too great.

\section{Discussion}

Both long and short-term changes in the natural and social systems have affected the sustainability of agriculture. While some of the most important changes in the distant past involved precipitation, we have little direct evidence of how people in the remote past attempted to cope, other than by shifting from agriculture to stock raising and emigration. Our primary evidence is the advance and retraction of settlements and our chronological precision is often only on the order of centuries, whereas climate changes may be on decadal to centennial scales. Fortunately, our temporal resolution improves markedly with the advent of history and especially so in the most recent era. Nevertheless, despite imperfect information about changes in both the social and natural systems, it is evident that they have had mutual impacts. Sharp changes in precipitation have led to reorientation of society on several occasions. Changes rendered by humans on the landscape have also altered it over longer and shorter periods, in part to compensate for periods of aridity, or to profit from periods of abundance or economic opportunity. The changes in the social and natural systems are mutually reinforcing, as each responds to changes in the other. The keys to future success will be to gain a fuller understanding of natural variability and its causes and to understand the scales (both temporal and spatial) over which the critical systems operate or can be made to operate.

We have learned that climate is a global phenomenon that changes periodically, but even slight effects may have major impact on the sustainability of agriculture in the Fertile Crescent. Interannual variability is great enough today to cause significant loss of yields in dry years. If drought were to persist for a decade rather than the one or two years that is 
now observed every decade or so, it would be catastrophic. Whether the expected global warming will cause such conditions is still uncertain.

The Khabur River traverses many geological and political zones so that extraction inevitably impacts users downstream and ultimately the seas and oceans which are part of a global system. In the Near East political boundaries have led nations to develop separate priorities and policies that have potential regional implications. There are many cases where economic development in one county has affected downsteam users in another country. (Beaumont, 1981; Beaumont, 1996; Kolars, 1994, 2000). What is needed to sustain agriculture into the next decades, even if there is no global warming or other natural shock, is to think globally about water and land resources, when acting locally.

The critical question is whether, even with foresight and good will, the social systems will be able to sustain themselves while there is steady degradation of the land and water, or when the sudden onset and prolonged effects of the next severe climate change occurs (Table 4). If history is a guide, many social systems will not survive and those that do may be altered in fundamental ways. The natural global climate cycle of 1000-1500 years (1470+-520 years) (Bond et al., 1997) is paralleled in the semi-arid Khabur and elsewhere in the Near East, where cycles of settlement of a few hundred years are juxtaposed with a thousand or more years of virtual absence of settlement. Climate must be part of the reason for this coincidence even though specific evidence for this relationship remains a subject for research. It is sobering to realize, however, that none of the political entities known archaeologically or historically flourished for more than a few centuries. In this semi-arid landscape it has been difficult to sustain a social system: subsistence has repeatedly failed. The Near East generally, and the example of the Khabur, show that rain-fed agriculture is sustainable over the long term under stable or more favorable climate and if there is time for the land to regenerate from excessive exploitation or drought. Unfortunately, history seems to show that regenerative periods last longer than those of agricultural exploitation (Hole and Smith, 2004).

Worldwide, the next 50 years are likely to be the final period of rapid agricultural expansion, driven by a wealthier and 50 percent larger human population (Tilman et al., 2001). The Near East has already approached the limits of agricultural expansion. Indeed the area devoted to agriculture may be diminishing as a result of depletion of soils and water, but the rate of population growth and its demand for ecological services has not yet diminished significantly.

Today's industrial approach to agriculture is fundamentally different from any in the past and there is no local experience for assessing its long-term viability on this fragile landscape although alarms have been raised (Beaumont, 1996; Rida et al., 2004) (Table 5). The next 50 years will tell whether we have learned enough to sustain the system in the face of inevitable and often unanticipated changes. Stay- ing the present course may, in the long run, be less successful than conceiving a new approach that would replace the present mix of policies and practices with a more integrated understanding of the socio-natural system that sustains us all.

Acknowledgements. Funding for the land use studies was from NASA NAG5-9316 "Landscape Changes in the Middle East: A Regional Assessment Using Remote Sensing," and analysis of land use changes were carried out in Yale's Center for Earth Observation. Archaeological research was supported by NSF-SBR-9515394, NSF-SBR-9510543, NSF-BNS-9012337, and National Geographic grant 3832-88. A Digital Atlas of photographs of the region can be seen at www.yale.edu.ceo/Projects/Swap.html.

Edited by: J. Brigham-Grette

\section{References}

Adams, R. M.: Heartland of Cities, University of Chicago Press, Chicago, 1981.

Akkermans, P. M. M. G. and G. M. Schwartz: The Archaeology of Syria From Complex Hunter-Gatherers to Early Urban Societies (ca. 16,000-300 BC), Cambridge World Archaeology, Cambridge University Press, Cambridge, 2003.

Alley, R. B., Mayewski, P. A., Sowers, T., Stuiver, M., Taylor, K. C., and Clark, P. U.: Holocene climatic instability: widespread event at 8200 years ago, Geology, 25, 483-486, 1997.

Alley, R. B., Marotzke, J., Nordhaus, W. D., Overpeck, J. T., Peteet, D. M., Pielke, Jr., R. A., Pierrehumbert, R. T., Rhines, P. B., Stocker, T. F., Talley, L. D., and Wallace, J. M.: Abrupt climate change, Science, 299, 2005-2010, 2003.

Avner, U.: Settlement, agriculture and paleoclimate in 'Uvda Valley, Southern Negev desert, 6th-3rd millennia BC, in: Water, Environment and Society in Times of Climatic Change, edited by: Issar, A. S. and Brown, N., International Workshop within the Framework of International Hydrological Program (IHP), UNESCO, Klewer Academic Publishers, Dordect, pp. 147-202, 1998.

Bar-Matthews, M., Ayalon, A., and Kaufman, A.: Middle to Late Holocene (6,500 Yr. period) paleoclimate in the eastern Mediterranean region from stable isotopic composition of speleothems from Soreq Cave, Israel, in: Water, Environment and Society in Times of Climatic Change, edited by: Issar, A. S. and Brown, N., International Workshop within the Framework of International Hydrological Program (IHP), UNESCO, Klewer Academic Publishers, Dordect, pp. 203-214, 1998.

Bar-Matthews, M., Ayalon, A., Kaufman, A., and Wasserburg, G.: The Eastern Mediterranean paleoclimate as a reflection of regional events: Soreq Cave, Israel, Earth Planet. Sci. Lett., 166, 85-95, 1999.

Bar-Yosef, O. and Belfer-Cohen, A.: Facing environmental crisis, societal and cultural changes at the transition from the Younger Dryas to the Holocene in the Levant, in: The Dawn of Farming in the Near East, edited by: Cappers, R. T. J. and Bottema, S., Studies in Early Near Eastern Production, Subsistence, and Environment, 6, 1999. Vol. 6. ex oriente, Berlin, pp. 55-66, 2002.

Beaumont, P.: Water resources and their management in the Middle East, in: Change and Developments in the Middle East: Essays 
in Honor of W. B. Fisher, edited by: Clarke, J. I. and BowenJones, H., London, pp. 40-72, 1981.

Beaumont, P.: Agricultural and environmental changes in the Upper Euphrates catchment of Turkey and Syria and their political and economic implications, Appl. Geogr., 16, 137-157, 1996.

Blumler, M. A.: Ecology, evolutionary theory and agricultural origins, in: The Origins and Spread of Agriculture and Pastoralism in Eurasia, edited by: Harris, D. R., University College Press, London, pp. 25-50, 1996.

Bond, G., Showers, W., Cheseby, M., Lotti, R., Almasi, P., deMenocal, P., Priore, P., Cullen, H. M., Hajdas, I., and Bonani, G.: A pervasive millennial-scale cycle in North Atlantic Holocene and glacial climates, Science, 278, 1257-1266, 1997.

Bond, G. C. and Lotti, R.: Iceberg discharges into the North Atlantic on millennial time scales during the last glaciation, Science, 267, 1005-1010, 1995.

Buccellati, G.: 'River bank', 'high country', and 'pasture land': the growth of nomadism on the middle Euphrates and the Khabur, in: Tall al-Hamidiya 2, edited by: Eichler, S., Wäfler, M., and Warburton, D., Vandenhoeck and Ruprecht, Göttingen, 1990.

Charles, H.: Tribus moutonnières du Moyen Euphrate, Institut française d'études arabes de Damas, Damascus, 1939.

COHMAP: Climatic changes of the last 18,000 years: observations and model simulations, Science, 241, 1043-1052, 1988.

Dean, W. E., Forester, R. M., and Bradbury, J. P.: Early Holocene change in atmospheric circulation in the Northern Great Plains: an upstream view of the 8.2ka cold event, Quatern. Sci. Rev., 21, 1713-1775, 2002.

Dodge, B.: The settlement of the Assyrians on the Khabur, Journal of the Royal Central Asian Society, 27, 301-320, 1940.

Enzel, Y., Bookman, R. B. T., Sharon, D., Gvirtzman, H., Dayan, U., Ziv, B., and Stein, M.: Late Holocene climates of the Near East deduced from Dead Sea level variations and modern regional rainfall, Quatern. Res., 60, 263-273, 2003.

Enzel, Y., Ely, L. L., Mishra, S., Ramesh, R., Amit, R., Lazar, B., Rajaguru, S. N., Baker, V. R., and Sandler, A.: High-resolution Holocene environmental changes in the Thar Desert, Northwestern India, Science, 284, 125-128, 1999.

Epstein, E.: Al Jezireh, Journal of the Royal Central Asian Society, 27, 68-82, 1940.

FAO: Etude des Resources en Eaux Souterraines de la Jazireh Syrienne, Food and Agriculture Organization of the United Nations, 1966.

Gasche, H. H. and Tanret, M. (Eds.): Changing Watercourses in Babylonia: Towards a Reconstruction of the Ancient Environment in Lower Mesopotamia, University of Ghent and the Oriental Institute of the University of Chicago, Ghent, 1999.

Glennon, R.: The perils of groundwater pumping, Issues in Science and TEchnology (Fall), 73-79, 2002.

Grafenstein, U. v., Erienkeuse, H., Brauer, A., Jouzel, J., and Johnson, S. J.: A mid-European decadal isotope-climate record from 15,500 to 5000 years B. P., Science, 284, 1654-1657, 1999.

Hassan, F. A.: Mid-Holocene environments and human responses, Q. Rev. Archaeol., 5(4), 15-16, 1984.

Hassan, F. A.: Droughts, Food and Culture: Ecological Change and Food Security in Africa's Later Prehistory, Kluwer Academic/Plenum Publishers, New York, 2002.

Hole, F.: Environmental instabilities and urban origins, in: Chiefdoms and Early States in the Near East: The Organizational Dy- namics of Complexity, edited by: Stein, G. and Rothman, M., Monographs in World Archaeology, No. 18, Prehistory Press, Madison, pp. 121-151, 1994.

Hole, F.: Evidence for mid-Holocene environmental change in the western Habur drainage, northeastern Syria, in: Third Millennium BC Climate Change and Old World Collapse, edited by: Dalfes, H. N., Kukla, G., and Weiss, H., NATO ASI Series, Vol. 149, Springer-Verlag, Berlin, Heidelberg, pp. 39-66. 1997a.

Hole, F.: Paleoenvironment and human society in the Jezireh of northern Mesopotamia 20,000-6,000 BP, Paléorient, 23(2), 3949, $1997 b$.

Hole, F.: The prehistory of the Khabur, in: La Djéziré et l'Euphrate Syriens de la protohistoire à la fin du second millénaire av. J. C.: tendances dans l'interprétation historique des données nouvelles, edited by: Rouault, O. and Wäfler, M., Subartu, Vol. 7. Brepols, Turnhout, pp. 16-27, 2000.

Hole, F.: Climatic variability and the logic of ancient settlement patterns, in: Proceedings of the 2nd International Congress on the Archaeology of the Ancient Near East, edited by: Thuesen, I., Carsten Niebuhr Institute, University of Copenhagen, Copenhagen, 2002.

Hole, F. and Smith, R.: Arid land agriculture in northeastern Syria; will this be a tragedy of the commons?, in: Land Change Science: Observing, Monitoring, and Understanding Trajectories of Change on the Earth's Surface, edited by: Gutman, G., Janetos, A. C., Justice, C. O., Moran, E. F., Mustard, J. F., Rindfuss, R. R., Skole, D., Turner, B. L. I., and Cochrane, M. A., Remote Sensing and Digital Image Processing, Vol. 6, van der Meer, F. D. (General Editor), Kluwer Academic Publishers, Dordrecht/Boston/London, pp. 209-222, 2004.

Htteroth, W.-D.: Settlement desertion in the Gezira between the 16th and 19th century, in: The Syrian Land in the 18th and 19th Century: The Common and the Specific in the Historical Experience, edited by: Philipp, T., Vol. 5, Franz Steiner Verlag, Stuttgart, pp. 285-294, 1992.

Issar, A. S. and Zohar, M.: Climate Change - Environment and Civilization in the Middle East, Springer, New York, 2004.

Kennedy, D. and Riley, D.: Rome's Desert Frontier From the Air, University of Texas Press, Austin, 1990.

Keys, D.: Catastrophe. An Investigation Into the Origins of the Modern World, Ballantine Books, New York, 1999.

Kolars, J.: Managing the impact of development: the Euphrates and Tigris Rivers and the ecology of the Arabian Gulf - a link in forging tri-riparian cooperation, in: Water as an Element of Cooperation and Development in the Middle East, edited by: Bagis, A. I., Hacettepe University and Friedrick Naumann Foundation, Ankara, pp. 129-153, 1994.

Kolars, J.: Defining the political/ecological threhold for the Euphrates and Tigris rivers, Arab Studies Quarterly, 22(2), 101$113,2000$.

Kouchoukos, N.: Landscape and Social Change in Late Prehistoric Mesopotamia, Ph.D., Yale University, 1998.

Kühne, H.: Dur-Katlimmu and the Middle-Assyrian empire, in: La Djéziré et l'Euphrate Syriens de la Protohistoire à la fin du IIe millénaire av. J.-C., edited by: Rouault, O. and Wäfler, M., Vol. 7. Brepols, Turnhout, pp. 271-277, 2000.

Layard, A. H.: Discoveries in the Ruins of Nineveh and Babylon, London, 1853.

Luke, J. T.: Pastoralism and Politics in the Mari Period: a re- 
examination of the character and political significance of the major west Semitic tribal groups on the Middle Euphrates, ca. 18281758 B. C., Ph.D., University of Michigan, 1965.

Margueron, J.-C.: Mari, l'Euphrate, et le Khabur au milieu du IIIe millénaire, Bulletin of the Canadian Society for Mesopotamian Studies, 21, 79-100, 1991.

McCorriston, J. and Hole, F.: The ecology of seasonal stress and the origins of agriculture in the Near East, American Anthropologist, 93(1), 46-69, 1991.

Mensing, S. A., Benson, L. V., Kashgarian, M., and Lund, S.: A Holocene pollen record of persistent droughts for Pyramid Lake, Nevada, USA, Quatern. Res., 62, 29-38, 2004.

Moore, A. M. T. and Hillman, G. C.: The Pleistocene to Holocene transition and human economy in Southwest Asia: the impact of the Younger Dryas, American Antiquity, 57, 482-494, 1992.

Nester, M.: Population growth and decline in the northern part of Eretz-Isarel during the historic period as related to climatic changes, in: Water, Environment and Society in Times of Climatic Change, edited by: Issar, A. S. and Brown, N., International Workshop within the Framework of International Hydrological Program (IHP), UNESCO, Klewer Academic Publishers, Dordect, pp. 129-145, 1998.

Neumann, J. and Parpola, S.: Climatic change and the eleventhtenth-century eclipse of Assyria and Babylonia, Journal of Near Eastern Studies, 46, 161-182, 1987.

Pascual, J.-P.: II - La Syrie è l'époque ottomane (le XIXe siècle), La Syrie Aujourd'hui, 31-53, 1980.

Rida, F., Aw-Hassan, A., and Bruggeman, A.: Sustainable use of groundwater in Syria, ICARDA Caravan, (20/21), 22-23, 2004.

Robinson, C. F.: Tribes and nomads in early Islamic northern Mesopotamia, in: Continuity and Change in Northern Mesopotamia from the Hellenistic to the Early Islamic Period, edited by: Bartl, K. and Hauser, S. R., Berliner Beiträge zum Vorderen Orient, Haas, V., Kühne, H., Nissen, H. J., and Renger, J. (General Editors), Dietrich Reimer Verlag, Berlin, pp. 429452, 1996.

Rohling, E. J. and Pälike, H.: Centennial-scale climate cooling with a sudden cold event around 8,200 years ago, Nature, 434, 975979, 2005.
Sachau, E.: Reise in Syrien und Mesopotamien, Leipzig, 1883.

Sage, R. F.: Was low atmospheric CO2 during the Pleistocene a limiting factor for the origin of agriculture?, Global Change Biology, 1, 93-106, 1995.

Tilman, D., Fargione, J., Wolff, B., D’Antonio, C., Dobson, A., Howarth, R., Schindler, D., Schlesinger, W. H., Simberloff, D., and Swackhamer, D.: Forecasting agriculturally driven global environmental change, Science, 292, 281-284, 2001.

USAID: Land classification and soil survey project of the Syrian Arab Republic, Reconnaissance Soil Survey 1:500,000 2. United States Agency for International Development and the Syrian Arab Republic, Washington, D. C., 1982

USDA: Syria: Agricultural Sector Assessment, 5 Vols., United States Department of Agriculture, Washington, D.C., 1979

van Berg, P.-L. M. and Picalause, V.: Structures archologique et art rupestre Kisham (Hassake, Syrie), Subartu, 10, 571-584, 2003.

van Berg, P.-L. M., Vander Linden, M., Lemaitre, S., Cauwe, N., and Picalause, V.: Desert-kites of the Hemma Plateau (Hasseke, Syrie), Palèorient, 30(1), 89-100, 2004.

Weiss, H.: Late Third Millennium Abrupt Climate Change and Social Collapse in West Asia and Egypt, in: Third Millennium BC Climate Change and Old World Collapse, edited by: Dalfes, H. N., Kukla, G., and Weiss, H., NATO ASI Series, Vol. 149, Springer-Verlag, Berlin, pp. 711-723, 1997.

Wilkinson, T. J.: The structure and dynamics of dry-farming states in Upper Mesopotamia, Current Anthropology, 35(5), 483-520, 1994.

Wilkinson, T. J.: Environmental fluctuations, agricultural production and collapse: a view from Bronze Age Upper Mesopotamia, in: Third Millennium BC Climate Change and Old World Collapse, edited by: Dalfes, H. N., Kulka, G., and Weiss, H., SpringVerlag, Berlin, pp. 67-106, 1997.

Zohary, D.: Domestication of the Southwest Asian crop assemblage of cereals, pulses and flax: evidence from the living plants, in: Foraging and FArming: the Evolution of Plant Exploitation, edited by: Harris, D. R. and Hillman, G. C., Unwin \& Hyman, London, pp. 359-373, 1989. 